|| ISSN(online): 2589-8698 || ISSN(print): 2589-868X || International Journal of Medical and Biomedical Studies

Available Online at www.ijmbs.info

PubMed (National Library of Medicine ID: 101738825)

Index Copernicus Value 2018: 75.71

Volume 3, Issue 4; April: 2019; Page No. 229-230

\title{
CHOLERA TREATMENT WITH BEETROOT BASED ORS IN MALNOURISHED CHILDREN
}

Chandrika Murugaiah ${ }^{1 *}$, Jasvinder Kaur ${ }^{2}$, Hassanain Al-Talib ${ }^{3}$, Mehru Nisha ${ }^{4}$, Liew Sat Lin Constance ${ }^{5}$, Atif Amin Baig ${ }^{6}$

${ }^{1}$ Faculty of Medicine and Health Sciences, University Malaysia Sabah, Jalan UMS, 88400, Kota Kinabalu, Sabah, Malaysia

${ }^{2}$ Department of Paeditrics, National University of Malaysia (UKM) Medical Centre

${ }^{3}$ Laboratory Medical Science Cluster, Faculty of Medicine, Universiti Teknologi MARA (UiTM), Sungai Buloh, 47000, Selangor, Malaysia

${ }^{4}$ Institute of Medical Science Technology, Universiti Kuala Lumpur (UniKL), A1-1, Jalan TKS 1, Taman Kajang Sentral, Selangor, 43000 Kajang, Selangor, Malaysia

${ }^{5}$ Medical Based Department, Universiti Malaysia Sabah, Kota Kinabalu, Sabah, Malaysia

${ }^{6}$ Faculty of Medicine, Universiti Sultan Zainal Abidin (UniSZA), Medical Campus, 20400 Kuala Terengganu, Terengganu, Malaysia

Article Info: Received 15 April 2019; Accepted 28 April. 2019

Cite this article as: Murugaiah, C., Kaur, J., Al-Talib, H., Nisha, M., Constance, L. S. L., \& Baig, A. (2019). CHOLERA TREATMENT WITH BEETROOT BASED ORS IN MALNOURISHED CHILDREN. International Journal of Medical and Biomedical Studies, 3(4).

DOI: https://doi.org/10.32553/ijmbs.v3i4.211

Address for Correspondence: Chandrika Murugaiah, Faculty of Medicine and Health Sciences, University Malaysia Sabah, Jalan UMS, 88400, Kota Kinabalu, Sabah, Malaysia

Conflict of interest: No conflict of interest.

\section{Perspective}

Cholera is an infection caused by the bacterium Vibrio cholerae that causes severe watery diarrhea, which can lead to dehydration. Symptoms may range from none, to mild, to severe with vomiting that may result in sunken eyes, cold skin, decreased skin elasticity, and wrinkling of the hands and feet. It is caused by eating food or drinking water contaminated with a bacterium called Vibrio cholerae with symptoms start two hours to five days after exposure.

Malnutrition in cholera is a condition that results from insufficient eating a diet in which one or more nutrients are either not enough that the diet causes health problems. Deficit may involve calories, protein, carbohydrates, vitamins or minerals. Normally malnourished children experience undernutrition or undernourishment where the childen is not getting enough calories, protein, or micronutrients. Malnutrition increases the risk weakens immune system. In cholera, protein and energy malnutrition and deficiencies of specific micronutrients (including iron, zinc, and vitamins) increase susceptibility to infection. Diarrhea and other infections can cause malnutrition through decreased nutrient absorption, increased metabolic requirements, direct nutrient loss, and decreased intake of food.

Oral rehydration therapy (ORT), potential decrease the risk of death from diarrhea by up to $93 \%$, is a type of fluid replacement used to prevent and treat dehydration. It involves drinking water with 
modest amounts of sugar and salts, specifically sodium and potassium in diarrhea patient. For more than 25 years WHO and UNICEF have recommended a single formulation of glucose-based Oral Rehydration Salts (ORS) to prevent or treat dehydration from diarrhea in children.To prevent too much liquid being lost from the child's body, food based oral rehydration solution can be made using ingredients found in almost every household. Food based ORS should contain: food and/or sugars as a source of glucose and energy, some sodium. We recommend here beetroot based ORS to be given to malnourished children.

Beetroot (Beta vulgaris) is a root vegetable also known as red beet, table beet, garden beet, or just beet. It is of exceptional nutritional value. Edible taproots and leaves (called beet greens) are rich in calcium, iron and vitamins $\mathrm{A}$ and $\mathrm{C}$. Packed with essential nutrients, beetroots are a great source of fiber, folate, folic acid, manganese and potassium. Raw beetroot is $86 \%$ water, $10 \%$ carbohydrates, $1.5 \%$ protein, and less than $3 \%$ fat. In every 100 -gram amount providing 85 calories, raw beetroot is a rich source of folate and a moderate source of manganese, with other nutrients having insignificant content. Beetroot based ORS can been given to the malnourished children after cooking then salt added combined with ORS. 